SCHOLARS: Journal of Arts \& Humanities

[Peer-Reviewed, Open Access Scholarly Publication] Indexed in NepJOL; JPPS Star-Ranked Journal

Print ISSN: 2773-7829; e-ISSN: 2773-7837

eJournal Site: www.cdetu.edu.np/ejournal/
Central Department of English

Tribhuvan University

Kirtipur, Kathmandu, Nepal

URL: $\underline{\text { www.cdetu.edu.np }}$

Theoretical/Critical Essay Article

\title{
The Nature-Human Relationship: An Ecocritical Reading of Self in Keats' Poem
}

\author{
Rajiv Gautam \\ Siddhalek Rural Municipality, Dhading, Nepal
}

Article History: Submitted 27 May 2021; Revised 30 June 2021; Accepted 5 August 2021

Corresponding Author: Rajiv Gautam, Email: grajiv58@yahoo.com

DOI: https://doi.org/10.3126/sjah.v3i2.39432

Copyright 2021 (C) The Author(s). The work is licensed under a Creative Commons Attribution 4.0 International License (CC BY 4.0).

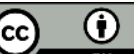

\begin{abstract}
This study analyzes the fusion of self and nature in John Keats's ode "Ode to a Nightingale" from ecocritical perspective. To do so, the ecocritical insights envisioned by Arne Naess, Bill Devall, George Sessions and Timothy W. Luke have been used as theoretical parameters to analyze the primary text. As the focus of the deep ecological trend, the uniformity between the human self and nature is represented in this text. This uniformity restores the significance of realizing the self with nature. This realization leads to the fusion. The fusion combines harmonious relationship between the self and nature to form a single entity. Due to this process, the selected primary text merges human beings and natural sublimity by means of a nightingale bird. When human beings cannot make positive attitude towards nature and act accordingly, their self does not get chance to be attached with nature. Nature is essential for all entities. The destruction of natural world causes the destruction of self. This destruction gets a solution only when there arises symbiotic bonding between human beings and nature. This bonding adds new knowledge in the existing scholarship being itself different from the previous research works.
\end{abstract}

Keywords: Fusion, self, nature, ecocritical perspective, deep ecology

\section{Introduction}

This study makes an attempt to explore and analyze the fusion of human self and nature in John Keats's ode "Ode to a Nightingale." In this ode, the sweet song of Nightingale drags Keats's speaker to the beautiful world of nature. He expresses his happiness with the happiness of this bird which sings the song of Summer freely. There arises the sense of forgetting all the worries to the speaker as he is fade up with the human world. He desires to drink something special so that he gets success to leave the human world and merge himself into the world of bird. His desire of drinking something special replaces with the idea of poetry. Using the wings of his imagination, he wishes to fly on its world. Due to the blocking trees, the moonlight night does not pass its light to his ways. Even in this darkness, he feels the sweet smells of diverse plants as per the 
season. The darkness in his loneliness gives him the sense of metamorphosis. He compares the world of Nightingale with his own world. The comparison makes him tragic in the sense that humans have to die one day but the bird is not born for death. He gives the remark of immortality to the bird. The song of this bird continues from the past to the present time. The sense of fusion energizes his self but returning back to the real world after elaborating the beautiful world of Nightingale makes him puzzled. He imagines the sad picture of human world after returning back to the reality. Due to this, human self gets its attachment with nature by the means of fusion which is indicated through the songs of Nightingale in the ode.

The main theoretical perspective to analyze the fusion of self and nature in the representation of primary text is ecocriticism. Ecocriticism in the words of Cheryll Glotfelty means "the study of the relationship between literature and the physical environment" (87). It presents the interconnection of nature with human beings. In this sense, it takes the "earth-centered approach to literary studies" (87). It advocates for preserving the earth community. It shows the dissatisfaction of selfish activities conducted by people. "As a critical stance, it has one foot in literature and the other on land; as a theoretical discourse, it negotiates between the human and the nonhuman" (Glotfelty 88). The negotiation becomes effective when people make positive attitude to protect ecological harmony.

Among the various trends of ecocriticism, this study focuses on deep ecology. Deep ecology claims for maintaining non-hierarchical ecological consciousness by rejecting the notion of anthropocentrism which means human at the center. Defining deep ecology as political philosophy, Timothy W. Luke brings the reference from the deep ecologists Arne Naess, Bill Devall and George Sessions to talk about the concept of self, nature and fusion. "The self is extended and deepened as a natural process of the realization of its potentialities in others" (Naess 59). It becomes supportive to realize one in all and all in one. It also helps to cultivate the habit of maintaining ecological consciousness. "The foundations of deep ecology are the basic institutions and experiencing of ourselves and Nature which comprise ecological consciousness" (Luke 5). When we maintain ecological consciousness, we find everything in balancing order in our surrounding. In our surrounding, the landscapes with trees support to refresh our mind. "A study of the therapeutic value of trees for hospital patients found that, compared with patients whose windows looked out onto brick walls, those whose windows gave them a view of trees required fewer painkillers and were discharged earlier" (Gifford 173-174). Trees have power to make our mind healthy. Healthy mind leads to healthy life. Trees exist on land and humans sustain their healthy life on the same land. Land, in this sense, does not refer only the soil but it refers "a fountain of energy flowing through a circuit of soil, plants, and animals" (Leopold 43). It gives equal reverence to human self and nature. This reverence of human self and nature functions through the medium of fusion which means the process of joining two or more things together to form a single entity. Luke highlights the "fusion of human self with the 'organic wholeness' of Nature's self" (9). This fusion is supportive to carry out the gist of deep ecology.

\section{Realizing the Self with Nature}

The self of Keats's speaker in "Ode to a Nightingale" gets attached with Nightingale. The song of Nightingale trails him to the natural world where he realizes his self with the medium of comparison. After hearing the song, he goes to the level of realizing his self. His self-realization gives him the sense of maturity. The deep ecological sense of self as defined by Luke "requires a further maturity and growth, an 
identification which goes beyond humanity to include the nonhuman world" (6). This maturity leads the speaker's self towards the world of the Nightingale. Keats hints this self with the lines "'Tis not through envy of thy happy lot, / But being too happy in thine happiness - / That thou, light-winged Dryad of the trees" (5-7). Using a punctuation mark called dash (-), and the terms "thy," "thine" and "thou," the speaker here addresses the bird, Nightingale as human beings. He posits his mental turmoil with the term "'Tis." Using the expression "'Tis not," he says he does not have any jealousy with the happiness of the bird. Instead, he shares his happiness. The term "too" refers to his happiness. This happiness assists for realizing his self with the bird. The expression "Dryad" means nymph where the bird, Nightingale is presented as a "light-winged" nymph of "the trees." It shows that the bird itself is a symbol of nature. With this reality, the speaker realizes his self with the nature.

Nightingale is a symbol of the natural world in "Ode to a Nightingale." The speaker exalts the song of a Nightingale. Exalting the Nightingale's song is exalting the nature. Being "a part of nature" (Rolston III 134), Nightingale attracts anyone to experience how beautiful the nature is and how nature manages the things systematically. Linking the same issue, Jonathan Bate highlights James Hutton's "Theory of Earth" which seeks to "demonstrate that 'there is a system in nature' and that in the long perspective of geological time nature's economy is benign" (78). Nature has its own system. Within this system, it connects everything in a friendly manner. This connects the melody of Nightingale where Keats expresses, "In some melodious plot / Of beechen green, and shadows numberless, / Singest of summer in full-throated ease" (8-10). The term "plot" here refers to space. Nightingale has capacity to make any space melodious. The space is beech tree. The term "numberless" is innumerable or countless. The green beech tree has countless shadows where the Nightingale sits and sings the song of the Summer season. The expression "full-throated" refers to the solo performance of Nightingale which is similar to an opera singer. Like this, Nightingale sings freely in a friendly manner inspiring anyone realize about the beauty of nature.

The association of human self with nature is the way of maintaining cordial relationship. This association supports for avoiding domination of one over another. From the perspective of deep ecology, everything has equal value on this earth. If one tries to go to the center then there appears mismatch between center and margin. Unlike this association, John Daniel writes, "But long-term association with a place no more guarantees good stewardship than a long-term marriage guarantees a loving and responsible relationship" (262). He compares a long-term association of place with a long-term marriage. What he writes is the assumption of common people. Normally, people believe that marriage becomes loveless with the increasing pattern of time. Likewise, the long-term connection with a place does not guarantee good relation. But both the issues do not stand on real ground. In "Ode to a Nightingale," the speaker has desire to drink something special that takes him to the world of Nightingale. He expresses his desire with the announcement "That I might drink, and leave the world unseen, / And with thee fade away into the forest dim" (19-20). He is ready to drink the thing that drives him to the unseen world of Nightingale. This world or place is the dark forest where he can live enjoying its beauty forever. As a whole, the association of self with nature's beauty becomes supportive for maintaining friendly relationship which lasts for long period of time.

The self of human and nature correspond with each other for non-hierarchical ecological consciousness. This consciousness supports for carrying out nature friendly activities. To address this ecological consciousness, William Wordsworth indicates, "I wandered lonely as a cloud / That floats on high o'er vales and hills" (1-2). With these 
lines, he shows his integration with nature. The term "cloud" represents his own image and he is back to nature for maintaining ecological consciousness. This consciousness links through the remark of "O, for a draught of vintage! that hath been / Cooled a long age in the deep-delved earth" (11-12). The term "draught" here means the act of drinking and "vintage" means the wine of a high quality. When the Nightingale sings the song of Summer without any fear then the speaker craves for drinking vintage that helps him to be cool for long time on this earth. With this vintage, he gets energy to relate his existence with Nightingale's world.

The realization of self with nature promotes ecological living going beyond the formation of industrial society. In the industrial society, technology drives for the mass production. This society works as a replacement of agrarian society. Luke as a deep ecologist connects this issue indicating "deep ecologists turn to repressed, ignored, or forgotten visions of ecological living, which persist beneath, behind, or beyond the existing structures of industrial society" (4). His connection is important because the realization of self with nature is possible through this connection to promote neglected perception of ecological living. In the modern industrial world, people with commercial motive have no time to glorify Nightingale's world as in the poem. The speaker admires the song of the Nightingale. He admires it stating, "The voice I hear this passing night was heard / In ancient days by emperor and clown" (63-64). By these lines, he says that people from generations are hearing its song. The terms "was heard" and "hear" show the continuity from the immemorial past to the present time. He now hears the same song which in ancient time was heard by the emperors and the clowns. With this, he realizes his self with the song of the Nightingale. His realization of self with nature gives value to ecological living.

\section{Connecting Self with Nature: A Textual Analysis of Keats' Poem}

The poem "Ode to a Nightingale" interconnects speaker's self with nature. The speaker desires his life to go with nature through the description of Nightingale. His desire brings them together connecting human and nature. As Barry Commoner mentions, "Everything is connected with everything else" (33), the connection here is between human and nature. This connection is essential for Bate too. Focusing this connection, he writes, "'The economy of Nature' and the human economy are brought together as the hand of man is 'incorporated with and subservient to the powers and processes of Nature."'(84). Here, the term "economy" means connection or interdependence. Human connection with nature is practicable as human is obedient towards nature. With this obedience, the connection becomes strong. The speaker in the poem is also obedient to the world of Nightingale. It is due to this obedience that he desires to enjoy his life dissolving himself into the world of Nightingale. He expresses this with the remark, "Fade far away, dissolve, and quite forget / What thou among the leaves hast never known / The weariness, the fever, and the fret" (21-23). With these lines, he dreams to go away from this real world to vanish himself into the Nightingale's world. He wants to forget those things that the Nightingale has never known in its kingdom. Fading away from the real world, he wishes to dissolve into the bird's world. The term "leaves" indicates Nightingale's settlement. With the means of interconnection, the speaker dreams of vanishing himself into the Nightingale's kingdom forgetting all the anthropogenic worries from the human world so that he can get chance to attach his self with nature and lead life joyfully like that of Nightingale.

The interconnection between human self and nature is fusion. This fusion applies with the medium of coparticipation. Coparticipation simply means joint participation which works for making the bonding of human self and nature stronger. Bringing this 
reference of coparticipation, Luke elucidates, "By seeing Nature as a significant form of otherness with properties of sentient subjectivity, deep ecology proposes new norms of human responsibility to change the human exploitation of Nature into coparticipation with Nature" (2). Nature is a form of otherness with the property of sentient subjectivity. Sentient is the ability to perceive or feel things. By this means of experiencing subjectivity, deep ecology shows its central focus on coparticipation. The responsibility of human being is not to exploit nature but to coparticipate with nature. This norm applies in Keats's "Ode to a Nightingale." It is due to this norm that the speaker in the poem does not want to exploit the nature. He wants to coparticipate with it moving himself into the world of Nightingale. For that, he uses the wings of his own poetry to join with the Nightingale and says:

Away! away! for I will fly to thee,

Not charioted by Bacchus and his pards,

But on the viewless wings of Poesy,

Though the dull brain perplexes and retards:

Already with thee! tender is the night,

And haply the Queen-Moon is on her throne,

Clustered around by all her starry Fays (31-37)

Here, the term "I" refers to the speaker and the term "thee" refers to the Nightingale. By using these two terms, the speaker expresses his desire of flying away from this human world to join with the world of the Nightingale. The term "away" indicates that Nightingale's world is far from the world where he lives. It implies that he is fade up with his world. "Bacchus" is the Roman god of wine, often depicted in a chariot drawn by leopards. In the earlier stanzas, the speaker expresses his desire of dissolving Nightingale's world by drinking wine like that of vintage. But here he realizes that wine does not take him to the world of Nightingale. Rather, he has to use the invisible wings of his own poetry to join with Nightingale. The "wings" here means the different types of word games used in poetry. The term "perplex" means baffle or puzzle and "retard" means delay or hold back. These terms declare that even though his brain makes him puzzled and delayed, he is hopeful to join with Nightingale by the impressive word games of poetry. He also mentions what happens after he joins with the Nightingale. The expression "Already with thee! tender is night" indicates that even the night becomes soft or loving after he joins with the Nightingale. The appearance of moon in the sky makes night further soft or loving. This moon is clustered or accompanied by the stars. The term "starry" means full of or lit by stars and "fays" means fairies. Like this, the speaker desires beautiful aspect of nature by the means of coparticipation to blend his self with Nightingale.

It is the same technique of fusion that has made the nexus between self and nature convincing. For this convincing nexus, we need to find our existence in others and others' existence in ourselves. If we fail to give equal response to others, we will not get equal response from others. Focusing the value of one in other, Naess advises, "We increasingly see ourselves in others, and others in ourselves. The self is extended and deepened as a natural process of the realization of its potentialities in others" (59). There is linkage between one and other. Seeing one in other and other in one makes good sense. It is natural to extend self for realizing its potentialities with others. The speaker in "Ode to a Nightingale" extends his self to realize Nightingale's world within himself. After flying into the Nightingale's world, even the darkness makes sense to him. He elucidates it saying, "I cannot see what flowers are at my feet, / Nor what soft incense hangs upon the boughs, / But, in embalmed darkness, guess each sweet" (41-43). Here, the term "incense" means perfume or fragrance and "boughs" means branches of a tree. 
The Nature-Human Relationship: An Ecocritical Reading of Self 121

Due to the darkness, neither he can see the types of flowers that are at his feet nor the softness of incense that hangs upon the branches of the trees. But, even in darkness, he can guess the sweet smell as per the season. The term "embalmed" means perfumed. The sweet smell makes the darkness perfumed. The dark kingdom of Nightingale provides existence to the speaker to merge his self with sweet perfume of the beautiful tress making their nexus convincing.

The fusion between self and nature is essential because it gives equal value of every member of earth community to form the community as a single organic entity. This value avoids all sorts of boundaries to maintain interrelation. This interrelation treats everything in an impartial manner. To maintain this impartiality, Luke cites the issue of biocentirc equality presented by Devall and Sessions where they claim, "Biocentirc equality is intimately related to the all-inclusive Self-realization in the sense that if we harm the rest of Nature then we are harming ourselves. There are no boundaries and everything is interrelated" (6). Biocentric equality focuses on the equal rights of all things to live and blossom. It belongs to all-inclusive Self-realization. It focuses on the belief that harming other is harming the self. The speaker expresses this convincing, "Wherewith the seasonable month endows / The grass, the thicket, and the fruit tree wild; / White hawthorn, and the pastoral eglantine" (44-46). The term "endows" means provides or supplies. Likewise, "thicket" means a dense group of bushes or trees, "hawthorn" means a thorny shrub or tree of the rose family and "pastoral" means rustic and "eglantine" means sweetbrier or wood rose. Even though the darkness creates obstacles to see the things, the speaker perceives the things as the seasonable month supplies. He internalizes all the grass, thicket, wild fruit tree, white hawthorn and pastoral eglantine as per the season. This perceiving is possible only through his interrelation with Nightingale.

It is due to the organic entity that there does not appear any hierarchy between self and nature. The focus of organic entity is on living being. This case makes us think about nature itself. The question of Ionian Philosophers become relevant about this nature. They raise the question saying, "What is nature made of?" (Whitehead 399). This question obtains the answer in terms of stuff, or matter, or material. There are dualists "who accept matter and mind as on equal basis" (Whitehead 400). Due to this, Whitehead's definition of nature as organism gives value to organic entity. This entity equally treats the human and nature in Keats's "Ode to a Nightingale" dismantling all the hierarchies. It becomes clear when the speaker opines, "But here there is no light, / Save what from heaven is with the breezes blown / Through verdurous glooms and winding mossy ways" (38-40). The term "here" refers to the world of Nightingale which is nature itself. This "here" also indicates that the speaker is in Nightingale's world. There is "no light" due to darkness as the speaker talks about the night time. Using the term "but," he shifts his idea from the tender night to the night with no light. The habitat of the Nightingale is forest which is dark in itself because the trees obstruct to pass the light. The terms "breeze," "blown," "verdurous," "gloom" and "mossy" indicate that even though there is darkness with different plants, Nightingale's world is pleasing. It is just like what the heaven saves with the breezes blown. Even if it is only his fantasy, the speaker as a member of the organic entity maintains balance with nature.

The issue of immortality is supportive for the fusion of human self and nature. This issue comes under supernatural world as it is beyond the expectation of natural law. The deep ecologists connect this supernatural world with the natural world. Mentioning this connection, they come to the human world. Their primal mind also plays significant role for this connection. Linking this idea of natural, supernatural and human world with primal mind, Luke argues: 
The Nature-Human Relationship: An Ecocritical Reading of Self 122

'The natural and supernatural worlds are inseparable; each is intrinsically a part of the other. Humans and natural entities are in constant spiritual interchange and reciprocity,' because Devall and Sessions interpret the available anthropological evidence as indicating that 'the primal mind holds the totality of human-centered artifacts, such as language, social organization, norms, shared meanings, and magic, within the first world of Nature. For the primal mind there is no sharp break between humans and the rest of Nature.' (8-9)

Each part of the natural world links supernatural world as there is indivisible relation between them. Humans and natural entities maintain exchanging relations for the mutual benefits. This is because the primal mind occupies human-made objects like language, norms etc. within the first world of nature. As a result, this mind gets connection between human and nature. This relation between human and nature is relevant in "Ode to a Nightingale" by the issue of immortality. The speaker bridges this immortality of the supernatural world with the means of Nightingale. For that, he avows, "Thou wast not born for death, immortal Bird! / No hungry generations tread thee down; / the voice I hear this passing night was heard" (61-63). Referring the term "thou" to the Nightingale, he gives the quality of immortality to this bird. The term "hungry generations" refers to the future generation and "tread" means walk. The speaker says that this bird is not born for death and even the future generation cannot walk with this bird. The expression "was heard" refers back to the primal mind. The voice that the speaker heard last night was already heard by the primal mind. It symbolically suggests that Nightingale is the eternal beauty of nature and by extolling its eternal beauty, human beings can maintain their reciprocal relation with nature.

The relation between self and nature supports to get self-maturation to the human beings. For this maturation, humans need to have power for understanding the value of nature. The cause is that saving nature is the way of saving human life. Without understanding the real essence of nature, this concept of saving does not arise. Luke presents this relation with his remark, "By projecting selfhood into Nature, humans are saved by finding their self-maturation and spiritual growth in it" (16). The projection of selfhood into nature enables human beings to be saved with the realization of selfmaturation and spiritual growth. These maturation and growth are significant in "Ode to a Nightingale" too. The speaker in the last part of this ode presents his overview about imagination and reality. His imaginary world takes him back to the natural world of Nightingale. This world turns out to be the real one because this world attaches his self. The real world itself is tragic for him. His priority over the imaginary world implicitly focuses on the need for nature conservation. With this priority, he makes human beings cautious and imparts the lesson to avoid profit-oriented business activities on the earth community. Due to this, he discloses his situation of dilemma in the last part of the ode where he reveals, "Was it a vision, or a waking dream? / Fled is that music:- - Do I wake or sleep?" (79-80). When the bird, Nightingale flees away from him, he becomes confused whether he gets success to enter into the world of Nightingale or not. $\mathrm{He}$ questions to himself whether it is his vision or just a day dream because he is not sure whether he is woken up or slept. The main reason to arise this situation is none other than the charm of Nightingale's world. It is also the indication of his self-maturation and spiritual growth. He cannot imagine his life in the absence of nature.

\section{Conclusion}

We all have reasons 
for moving.

I move

to keep things whole. (Strand 14-17)

The above concluding lines mentioned in Mark Strand's poem "Keeping Things Whole" express the gist of the present study to illuminate how human beings are required to perform their conscious acts in favour of ecological balance. These acts assist for realizing their self to be embedded with nature. After this realization, they boost up knowledge for the fusion of their self with nature. "Ode to a Nightingale" imparts the concept of biospherical egalitarianism and interdependence through the fusion of self with nature. The concepts of biospherical egalitarianism and interdependence plead for non-hierarchical ecological consciousness for maintaining balance between human self and nature. The speaker of "Ode to a Nightingale" realizes his existence only with his attachment towards nature which is represented through the songs of Nightingale.

In a nutshell, the study concludes that human-nature harmonious relationship gives equal value to all entities. This relationship is possible through the attachment of human beings with natural harmony. The process of sustaining this relationship is the fusion of self and nature. With this fusion, human self and nature joins together to form the earth community as a single organic entity.

\section{Works Cited}

Bate, Jonathan. "The Economy of Nature." Ecocriticism: The Essential Reader, edited by Ken Hiltner, Routledge, 2015, pp. 77-96.

Commoner, Barry. The Closing Circle: Nature, Man and Technology, Alfred A. 1972.

Daniel, John. "A Word in Favor of Rootlessness." A Forest of Voices: Reading and Writing the Environment, edited by Anderson Chris and Lex Runciman, Mayfield Publishing Company, 1995, pp. 259-64.

Gifford, Terry. "The Social Construction of Nature." The Green Studies Reader: From Romanticism to Ecocriticism, edited by Laurence Coupe, Routledge, 2000, pp. 173-76.

Glotfelty, Cheryll. "Literary Studies in an Age of Ecological Crisis." The Ecocriticism Reader: The Landmarks in Literary Ecology, edited by Cheryll Glotfelty and Harold Fromm, The U of Georgia P, 1996, pp. xv-xxxvii.

Keats, John. "Ode to a Nightingale." The Norton Anthology of Poetry, edited by Margaret Ferguson et al., Norton, 2005, pp. 935-37.

Leopold, Aldo. "The Land Ethics." Environmental Ethics: An Anthology, edited by Andrew Light and Holmes Rolston III, Blackwell Publishers Ltd., 2003, pp. 3846.

Luke, Timothy W. Ecocritique: Contesting the Politics of Nature, Economy and Culture. U of Minnesota P, 1999.

Naess, Arne. "The Deep Ecological Movement: Some Philosophical Aspects." Ecocriticism: The Essential Reader, edited by Ken Hiltner, Routledge, 2015, pp. 47-61.

Rolston III, Holmes. "Naturalizing Values: Organisms and Species." Environmental Ethics: Readings in Theory and Application, edited by Louis P. Pojman et. al., Cengage Learning, 2017, pp. 130-43.

Strand, Mark. "Keeping Things Whole." The Magic of Words, edited by Shreedhar P. Lohani and Rameshwar P. Adhikary, M.K. Publishers and Distributers, 2000, pp. 115-16. 
Whitehead, A. N. "Nature as Organism." Literature and the Environment: A Reader on Nature and Culture, edited by Lorraine Anderson et al., Longman, 1999, pp. 167-76.

Wordsworth, William. "I Wandered Lonely as a Cloud." Elements of Literature, edited by Robert Scholes et al., Oxford UP, 2004, p. 616. 